\title{
The Role Of Stochastic Dominance In Determining Discount Rates In Tort Cases
}

David Gordon, University of Saint Francis, USA

\begin{abstract}
In this paper the basic responsibilities of a forensic economist are introduced. The role of the discount rate in this process is explained. Prior research on the choice of an appropriate discount rate is examined. The forensic economist must choose either a real rate of interest or a nominal rate. The choice is further compounded by the possible need to utilize a risk adjusted interested rate. The role of the variance and stochastic dominance is then examined. Different types of stochastic dominance are explained. It is found that the concept of stochastic dominance is a more general concept of risk than the variance and thus could be more accurate to use when evaluating future income streams in legal cases involving torts.
\end{abstract}

Keywords: Discount Rates, Stochastic Dominance, Forensic Economics

\section{INTRODUCTION}

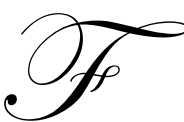

orensic economics is a discipline that deals with the process of estimating economic losses due to either accidental death or disability. Some of the variables that a forensic economist would use in their estimation of losses include base earnings, work life expectancy, growth rates in earnings fringe benefits and a discount rate. All of these areas are subjected to much debate in the literature. When establishing a dollar amount that should be granted to a plaintiff in a tort case, present value calculations must be employed. The need to compute present values necessitates the choice of an interest rate to use as the discount rate. This paper will center on the controversy associated with choosing appropriate discount rates and investigate the use of the concept of stochastic dominance in this matter. The role of the variance as an appropriate measurement of risk will be a focus of this investigation.

\section{DISCOUNT RATES}

When choosing an appropriate discount rate to utilize in forensic economics cases one has many decisions to make. A real rate of interest can be used that does not reflect any inflation premium or a nominal rate can be used that does reflect an adjustment for inflation. A risk free rate of interest can be used or some risk adjusted rate can be employed instead. The literature abounds with various opinions as to which is the correct interest rate to use as the discount rate. Everyone would agree that the discount rate used should be commensurate with the level of riskiness of the future income streams, but the riskiness of the income streams themselves is what is debated.

Many court decisions seem to support the use of a risk free rate. Two famous cases that clearly state the use of a risk free rate are Brown \& Root, Inc. v. Desautel (1977), which was a U.S. Court of Appeals case, and Jones \& Laughlin Steel Corp. v. Pfeifer (1983) which was a U. S. Supreme Court case. The Pfeifer court explicitly stated the discount rate "should not reflect the market's premium for investors who are willing to accept some risk of default". The issue of an inflation premium was not dealt with explicitly in either court case.

Previous work by Yandell (1991) and Albrecht and Wood (1997) have interpreted case law to mean that the discount rate should be both default free and inflation premium free. Others, such as Ireland (1999), have interpreted the cases as not requiring any adjustment for inflation risk. Recent surveys by Brookshire and Lesnick (1999) and Brookshire, Luthy and Lesnick (2003) on forensic economic practitioners tend to reinforce the interpretation of 
Ireland on this matter since most respondents utilize long term U. S. government securities as the appropriate benchmark for a discount rate.

Courts can obviously change their opinions on economic issues over time; therefore the economic arguments that still occur with regard to this issue are very pertinent since they might lead to a change in a court's future opinion on the issue. There exist a plethora of economic opinions on why risk should be introduced into the discount rate when valuing lost earnings. If these arguments are correct then by using a risk free discount rate the monetary awards in wrongful death or injury cases would overstate the true amount of economic damages. Most arguments center on the fact that in most cases future earnings are not a risk free cash flow stream. Earnings, like many other cash flow streams, are subjected to both unsystematic and systematic risks. Examples of unsystematic risks would include the possibility of the earner's skills becoming obsolete, natural occurring health problems, divorce and the disappearance of the industry the worker is employed in due to foreign competition. Examples of systematic risk include changes in overall worker productivity over time and unemployment due to the business cycle. Jennings and Phillips (1989) have discussed how the difference between actual earnings and expected earnings require earnings to be discounted back by a risk adjusted discount rate. Levhari and Weiss (1974) found that the rates of return on human capital can be riskier than the rates of return on physical capital. Henderson and Seward (1998) have found that using the risk free rate overstates the true economic damages in cases where bonds have asset betas greater than zero and where individuals are risk averse. Biederman and Baesemann (1996) have argued that risk free rates are only valid for cases where the decision maker is risk neutral or when discounting certainty equivalent cash flows.

There also exist many arguments in favor of using risk free rates as the discount rate even if not required to do so by law. Ireland (1999) has argued that since inflation involves both upside and downside risk there would be no adjustment needed to a risk free discount rate since any unanticipated variance in actual inflation only increases the variance and not the mean of future returns. He also argues that the riskiness of future earnings is dealt with by imposing reduced earnings for death and workforce attachment probabilities thus if a risky discount rate was also used in computing present values it would be imposing a double counting of risk resulting in a lower judgment for the plaintiffs than economically justified.

Breeden (2002) carries the discussion on the appropriate discount rate to use to a new plateau. He focuses on an "income-variance" risk factor in his work. He suggests that the year to year variance in projected earnings have not been properly accounted for in present value calculations. He points out that if uncertainty exists with regards to the constancy of projected income over time or uncertainty over the level of income from one year to the next then a different dimension of risk is present and needs to be accounted for in perhaps the discount rate. Breeden goes on to state that the decision in the Pfeifer case explicitly mentions the risk of default, but does not mention the risk associated with the variance of income from year to year. He goes on to conclude that the Supreme Court failed to "see" this income variance and the implications it might have on choosing a correct discount rate. It can be demonstrated that two individuals can have the same expected income yet one of the income streams would have the higher variance. Breeden is clearly suggesting that this higher variance should be interpreted as a riskier income stream and thus subject to a higher discount rate. One direct result would be to use a higher discount rate in tort cases involving a plaintiff who happened to be employed in an occupation exhibiting income that is more volatile than average. Many types of seasonal employment and occupations involving sales would fall into this category. The higher discount rate would of course result in a lower settlement amount being paid by the tortfeasor. This paper presents evidence suggesting the use of the variance cannot be applied universally as a proxy for risk and therefore should not be used to establish discount rates in court cases.

\section{STOCHASTIC DOMINANCE}

This author suggests that a more general and economically efficient method to measure the riskiness of future income streams is to use the concept of stochastic dominance. There are three well known degrees of stochastic dominance that have achieved much attention in the finance and economics literature. Each allows comparison of risky assets or income streams under certain conditions involving a decision maker's utility function. These conditions include typical assumptions concerning the non-satiation and risk aversion of the individual. Given that an individual is risk averse, stochastic dominance can be used as a measure of the relative riskiness of two 
different income streams. Ultimately the concept of stochastic dominance produces an answer regarding which income stream or asset is riskier given that a decision maker is risk averse. First order stochastic dominance (FOSD) can be used to compare the riskiness of income streams that do not have the same expected value. A necessary and sufficient condition for one income stream, say "A", to dominate another income stream on a first order basis, "B", would be if the cumulative distribution function of $\mathrm{A}$ is never greater than the cumulative distribution function of $\mathrm{B}$. In notational form, $\mathrm{A} \underset{F O S D}{\geq} \mathrm{B}$ is implied by $\mathrm{F}_{\mathrm{A}}(\mathrm{y}) \leq \mathrm{F}_{\mathrm{B}}(\mathrm{y})$ where " $\mathrm{y}$ " denotes income. This would also imply that the expected value of income stream A would be equal in distribution to the expected value of income stream B plus a nonnegative random variable. In notational terms we have $\tilde{y}_{\mathrm{A}} \stackrel{d}{=} \tilde{y}_{\mathrm{B}}+\alpha$ where $\alpha \geq 0$. This condition would imply that income stream A must have at least as high an expected value as income stream B. The reverse implication would not hold however.

Second order stochastic dominance (SOSD) is more applicable for our purposes in this paper. If income stream A dominates income stream B on a second order basis we write $\mathrm{A} \underset{S O S D}{\geq}$. This can occur if and only if the expected values for $\mathrm{A}$ and $\mathrm{B}$ are identical and $\mathrm{S}(\mathrm{z})=\int_{0}^{z}\left(\mathrm{~F}_{\mathrm{A}}(\mathrm{y})-\mathrm{F}_{\mathrm{B}}(\mathrm{y})\right) \mathrm{dy} \leq \forall \mathrm{z} \in[0,1]$ hold true. An equivalent way of presenting SOSD would be to assume the expected value of income stream $B$ is equal in distribution to the expected value of income stream A plus a random variable whose expected value is zero. In notational form we write, $\tilde{y}_{\mathrm{B}} \stackrel{d}{=} \tilde{y}_{\mathrm{A}}+\mathrm{e}$, with $\mathrm{E}\left[\mathrm{e} \mid \tilde{y}_{\mathrm{B}}\right]=0$. (SOSD is implied by FOSD and SOSD implies third order stochastic dominance (TOSD)). One important detail resulting from SOSD is that if $\underset{S O S D}{\geq}$ B this then implies that the variance of income stream A is never greater than the variance of income stream B. Even more importantly it can be shown that the converse does not hold true, a lower variance does not automatically imply anything with regards to SOSD, therefore information on the variance of income streams alone does not translate directly into information on the riskiness of the income streams. Special technical conditions must hold in order for differences in variances to have any implications on whether or not one income stream dominates another on a second order basis.

In finance it is current practice to discount riskier cash flow streams by a larger discount rate. Any textbook on the principles of financial management, such as Ross, Westerfield, and Jordan (2010) or Brealey, Myers and Allen (2008) emphasizes this procedure. When Breeden (2002) suggests the need for a higher discount rate based on the variance of income streams he cannot be basing this on the fact that one income stream is riskier than another in a general sense. He is clearly limiting his version of risk to simply mean the variance of future income streams. This is a constrained way of looking at risk and is contradicted by many results regarding stochastic dominance. Rothschild and Stiglitz (1970) concluded that a higher variance of future cash flows does not necessarily lead to a greater riskiness. Levy (1992) found that utility functions exist that result in the expected utility of the income stream with the higher variance being greater than the expected utility of the income steam with the lower variance, thus the income stream with the lower variance is not riskier in a Rothschild-Stiglitz sense for certain risk averters. A higher variance is a necessary condition of SOSD, but not a sufficient condition. A perhaps better way to measure the riskiness of income streams and thus the discount rates would be to apply the concepts of stochastic dominance when applicable. Applying these concepts in practice is not a purpose of this paper, but surely would be an area needed to be explored in future studies.

There are limited exceptions when applying the variance as the measurement of risk is appropriate. One exception is when we assume all individuals exhibit risk aversion and have quadratic utility functions. The quadratic function is frowned upon in finance due to it exhibiting increasing absolute and relative risk aversion. Another exception would be if we assume that income streams are normally distributed and all individuals have utility functions that exhibit risk aversion. The same exception would hold true for incomes that follow a lognormal distribution under the same restrictions on utility functions.

\section{SUMMARY AND CONCLUSION}

Choosing an appropriate interest rate to use as the discount rate when valuing items, such as lost earnings and foregone fringe benefits, is a very important responsibility of the forensic economist. Small differences in discount rates can add up to substantial differences in payouts to plaintiffs in civil cases. This is a major concern of 
both plaintiffs and defendants in tort cases. There exists much controversy with regard to the correct discount rate to utilize in these situations. U.S. courts have seemed to suggest using a risk-free rate of return as the discount rate. Breeden (2002) has questioned the way that U.S. courts have defined what is meant by risk. He suggests that the variance of future income streams should be accounted for in any discounting process. This would render a higher discount rate in cases where an individual's future earnings would be more variable and thus a lower present value dollar amount when computing settlement values. This paper suggests that a broader concept of risk be applied utilizing stochastic dominance. In this sense, if earnings stream " $A$ " stochastically dominates " $B$ ", we can say that B is riskier. A higher variance alone does not imply anything with regard to stochastic dominance, thus a higher variance does not automatically imply that a future income stream is necessarily riskier in a general sense. This, of course, would imply that a higher discount rate would not automatically apply in these cases. Future research is needed on how to more specifically apply the ideas of stochastic dominance to areas of forensic economics.

\section{AUTHOR INFORMATION}

David Gordon, DBA is an assistant professor in the College of Business and Health Administration at the University of Saint Francis (USF), Joliet, Illinois. He teaches both graduate and undergraduate classes in finance and economics. Prior to joining USF he held faculty positions at Illinois Valley Community College, the University of Illinois-Chicago and Governors State University. David was awarded numerous teaching awards during his academic career. Prior to earning his Doctorate in Business Administration he received a MA degree in economics and a BA degree in Finance from the University of South Florida in Tampa. He is currently a member of the American Economic Association, the International Financial Management Association, the National Association of Forensic Economics, the History of Economics Society, the Southern Economics Association and the Southern Finance Association. His research interest includes public finance, labor economics and forensic economics. He has published articles in various business and economics journals.

\section{REFERENCES}

1. Albrecht, Gary R. and John H. Wood, Risk and Damage Awards: Short Term Bonds vs. Long Term Bonds, Journal of Legal Economics, Vol. 7, No. 1, pp. 48-59, 1997.

2. Biederman, Daniel K. and Robert C. Baesemann, Risk Free vs. Risk Adjusted Discount Rates: A Comment, Journal of Forensic Economics, Vol. 9, No. 1, pp. 45-47, 1996.

3. Brealey, Richard A., Stewart C. Myers and Franklin Allen, Principles of Corporate Finance, McGraw-Hill Irwin, New York, New York, 2008.

4. Breeden, Charles H., The Income-Variance Risk Factor and Jones \& Laughlin v. Pfeifer Guidelines for the Calculation of Present Value, Journal of Forensic Economics, Vol. 15, No. 1, pp. 19-29, 2002.

5. Brookshire, Michael L., and Frank L. Slesnick, A 1999 Survey Study of Forensic Economists - Their Methods and Their Estimates of Forecast Variables, Litigation Economics Digest, Vol. 4, No. 2, pp. 65-99, 1999.

6. Brookshire, Michael L., Michael R. Luthy and Frank L. Slesnick, Forensic Economists, Their Methods and Estimates of Forecast Variables: A 2003 Survey Study, Litigation Economics Digest, Vol. 6, No. 2, pp. 28 44.

7. Caballe, Jordi and Joan Esteban, Stochastic Dominance and Absolute Risk Aversion, Social Choice Welfare, Vol. 28, No. 1, pp. 89-110, 2007.

8. Diamond, Peter A. and Joseph E. Stiglitz, Increases in Risk and in Risk Aversion, Journal of Economic Theory, Vol. 8, No. 3, pp. 337-360, 1974.

9. Fama, Eugene F., Risk Adjusted Discount Rates and Capital Budgeting under Uncertainty, Journal of Financial Economics, Vol. 5, No. 1, pp. 3-24, 1977.

10. Havrilesky, Thomas, New Evidence on Expected Long Term Real Interest Rates, Journal of Forensic Economics, Vol. 1, No. 2, pp. 19-23, 1988.

11. Henderson, James W. and J. Allen Seward, Risk Aversion and Overcompensation from the Risk Free Discount Rate, Journal of Legal Economics, Vol. 8, No. 2, pp. 25-32, 1998.

12. Ireland, Thomas, Response to Bell and Taub: Some Issues Concerning Risk Adjustements in Damage Calculations, Litigation Economics Digest, Vol. 4, No. 2, pp. 157-158, 1999. 
13. Ireland, Thomas, The Pfeifer Decision, Risk and Damage Awards: An Extended Response to Albrecht and Wood, Journal of Legal Economics, Vol. 7, No. 3, pp. 23-34, 1997.

14. Jennings, William P. and G. Michael Phillips, Risk as a Discount Rate Determinant in Wrongful Death and Injury Cases, The Journal of Risk and Insurance, Vol. 56, No. 1, pp. 122-127, 1989.

15. Levhari, David and Yoran Weiss, The Effect of Risk on the Investment in Human Capital, American Economic Review, Vol. 64, No. 6, pp. 950-963, 1974.

16. Levy, Haim, Stochastic Dominance and Expected Utility: Survey and Analysis, Management Science, Vol. 38, No. 4, pp. 555-593, 1992.

17. Machina, Mark J. and Michael Rothschild, Risk, Utility and Probability, pp. 227-239, The Macmillan Press, United Kingdom, 1990.

18. Margulis, Marc S., Compensatory Damages and the Appropriate Discount Rate, Journal of Forensic Economics, Vol. 6, No. 1, pp. 33-41, 1992.

19. Nowak, Laura S., Empirical Evidence on the Relationship between Earnings Growth and Interest Rates, Journal of Forensic Economics, Vol. 4, No. 2, pp. 187-202, 1997.

20. Ross, Stephen A., Randolph W. Westerfield and Bradford Jordan, Fundamentals of Corporate Finance, McGraw-Hill Irwin, New York, New York, 2010.

21. Rothschild, M. and Joseph Stiglitz, Increasing Risk I: A Definition, Journal of Economic Theory, Vol. 2, No. 2, pp. 225-243, 1970.

22. Rothschild, M. and Joseph Stiglitz, Increasing Risk II: Its Economic Consequences, Journal of Economic Theory, Vol. 3, No. 1, pp. 66-84, 1971.

23. Schmid, Freidrich, A Note on Third Degree Stochastic Dominance, OR Spectrum, Vol. 27, No. 4, pp. 653$655,2005$.

24. Whitmore, G. A., Third Degree Stochastic Dominance, American Economic Review, Vol. 60, No. 3, pp. 457-459, 1970.

25. Yandell, Dirk, The Value of Lost Future Earnings: Methodology, the Discount Rate and Economic Theory, Journal of Legal Economics, Vol. 1, No. 1, pp. 103-110, 1991. 


\section{NOTES}

